UNDERGRADUATE RESEARCH IN NATURAL AND CLINICAL SCIENCE AND TECHNOLOGY (URNCST) JOURNAL Read more URNCST Journal articles and submit your own today at: https://www.urncst.com

\title{
Potential Impact of Exercise-Associated Amenorrhea and Subsequent Estrogen Therapy on Cardiovascular Disease Risk Factors in Pre-menopausal Athletes: A Research Protocol
}

Niki Sadat Afjeh, BSc Student [1]*, Priyanka Lamba, BSc Student [1], Alefiya Eski, BSc Student [1]

[1] Department of Biology, McMaster University, Hamilton, Ontario, Canada, L8S 4L8

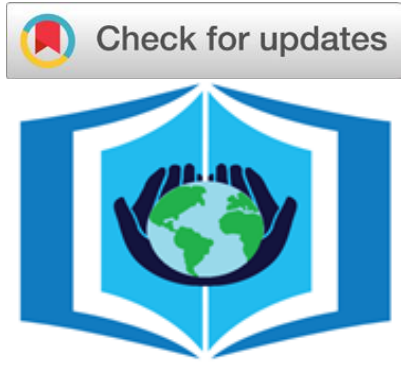

URNCST Journal

"Research in Earnest"

*Corresponding Author: $\underline{\text { sadatafs@mcmaster.ca }}$

\begin{abstract}
Introduction: Women with exercise-associated amenorrhea (EAA) have impaired pulsatile gonadotropin-releasing hormone $(\mathrm{GnRH})$ release that disrupts sufficient estrogen secretion, causing hypoestrogenism. As there is limited research on the influence of hypoestrogenism on cardiovascular health in pre-menopausal women, the purpose of this study is to assess its effect on the concentrations of estrogen and early cardiovascular diseases (CVD) risk factors - nitric oxide (NO), endothelin1 (ET-1), and E-selectin - in women with EAA.

Methods: A total of 90 participants between the ages of 18-35 will be selected based on the inclusion criteria of athleticism status (8 hours of structured physical activity/week) and body mass index (BMI) range of 18.5-24.5. Out of the 90 participants, 45 will have EAA and 45 will have regular menstrual status. Exclusion criteria: Smokers, women on contraceptives and those with pre-existing CVD and respiratory health conditions/family history of these conditions. Baseline data of estrogen and CVD risk factor concentrations will be obtained from all 90 participants through bi-weekly blood draws and serum analysis in the first month of the 7-month study. The amenorrheic, athletes ( $n=45)$ will receive $0.025 \mathrm{mg}$ of $17-\beta$ estradiol (E2) transdermally via estrogen patches daily for months 2-7 of the study. Blood will be collected bi-weekly from these amenorrheic, athletes $(\mathrm{n}=45)$ during months 2-7 to quantify estrogen and CVD risk factor concentrations during the intervention. Statistical analysis: 2-way Analysis of Variance (ANOVA) test to compare the levels of E2 and CVD risk factors prior to and following estrogen treatment of amenorrheic, athletic subjects.

Discussion: Although there are many cardiovascular risk factors which can be used as markers to determine the effect of EAA on cardiovascular health, NO, ET-1, and E-selectin may serve to provide more accurate analysis due to less present confounding factors as other markers. Anticipated results include increased NO and decreased ET-1 and E-selectin concentrations following estrogen therapy.

Conclusion: Diagnosis and management of menstrual irregularities like EAA is imperative for maintaining good cardiovascular health. Further research to determine whether estrogen therapy can be used as a long-term solution for women with EAA, and whether it should be provided in conjunction with nutritional intervention is recommended.
\end{abstract}

Keywords: amenorrhea; cardiovascular disease; nitric oxide; endothelin; E-selectin; estrogen deficiency; estrogen therapy; exercise-associated amenorrhea; hypothalamic axis; pre-menopausal women

\begin{abstract}
Introduction
Cardiovascular disease (CVD) is the leading cause of morbidity and mortality for women globally with an estimated 1 in 3 women dying from CVD each year [1]. Almost $50 \%$ of women over the age of 20 have some type of CVD and close to 25,000 women die from some form of CVD in Canada alone [2]. Yet, research suggests that premenopausal women are more protected against CVD compared to men of the same age [3]. There is considerable evidence that the ovarian hormone, estrogen, is a potent hormone that acts as a cardioprotective agent in premenopausal women and that a deficiency in estrogen in
\end{abstract}

post-menopausal women is associated with an increased risk of CVD [3].

E2 is the most dominant form of endogenous estrogen produced by the ovaries and helps play a vital role in numerous body systems including the vascular (cardiac and peripheral), skeletal, reproductive systems, and psychological health[4,5]. E2 is a particularly important factor for cardiovascular (CV) health as its regulatory interactions controls oxidative stress, allows for increased endothelial-cell growth, and ensures that blood flows to the myocardium through vasodilation [5]. The impact of estrogen deficiency (hypoestrogenemia) on the 
UNDERGRADUATE RESEARCH IN NATURAL AND CLINICAL SCIENCE AND TECHNOLOGY (URNCST) JOURNAL Read more URNCST Journal articles and submit your own today at: $\underline{\text { https://www.urncst.com }}$

cardiovascular system has been well-researched in postmenopausal women [5].

However, hypoestrogenemia can also occur in premenopausal women through disruptions in ovarian function. A major cause of this is reversible, functional hypothalamic amenorrhea (FHA) which is characterized by hypoestrogenemia and secondary amenorrhea [6]. As seen in Figure 1, FHA occurs when the hypothalamic-pituitaryovarian axis is disturbed such that the secretion of GnRH from the hypothalamus is suppressed [6]. This decreases the secretion of follicle-stimulating hormone (FSH) and luteinizing hormone (LH) from the anterior pituitary [6]. In turn, this disrupts ovarian function as the granulosa cells no longer receive a signal to synthesize $17-\beta$ estradiol, which leads to hypoestrogenemia (E2 $<50 \mathrm{pg} / \mathrm{ml}$ ) [5,6]. Moreover, the decreased levels of FSH $(<10 \mathrm{mIU} / \mathrm{ml})$ and $\mathrm{LH}(<10 \mathrm{mIU} / \mathrm{ml})$ during the follicular phase lead to reduced endometrial thickening resulting in amenorrhea [5,6]. Secondary amenorrhea is diagnosed as the lack of menstruation for at least three consecutive months in the absence of other ovarian and anatomic pathologies [5].

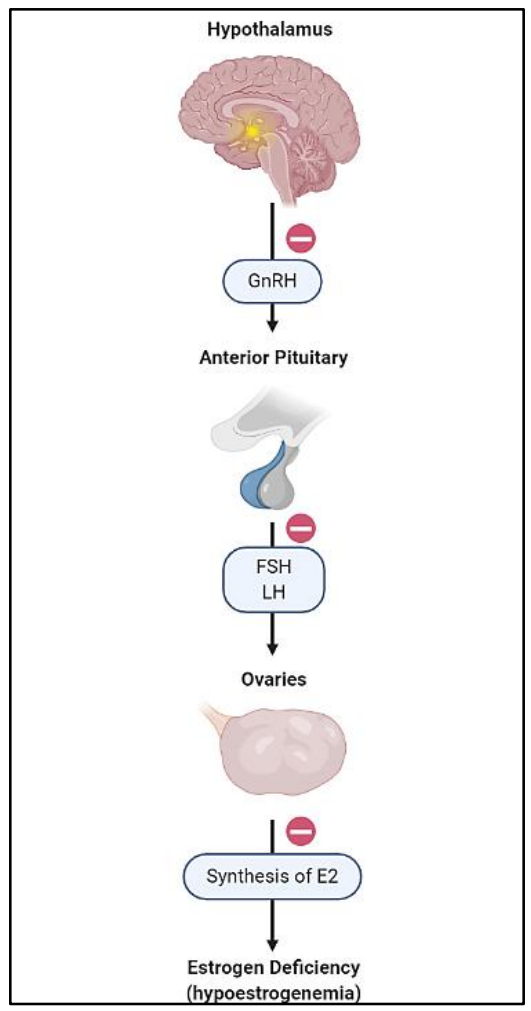

Figure 1. FHA. The hypothalamus-pituitary-ovarian axis is suppressed, leading to a decrease in the secretion of GnRH from the hypothalamus and a subsequent decrease in the secretion of FSH and LH from the anterior pituitary. This leads to a decrease in the synthesis and secretion of estrogen from ovarian granulosa cells, resulting in hypoestrogenemia. Figure adapted from [8]. Illustrated using BioRender.
There are three main types of FHA which are related to stress, weight loss, and exercise that occur in premenopausal women. An estimated 17.4 million premenopausal women are affected by some type of FHA worldwide [5]. Since estrogen is known to play a cardioprotective role, FHA-related hypoestrogenemia can have a negative impact on the cardiovascular system. Commonly, factors such as blood pressure, vascular conductance, and cholesterol levels are used as traditional markers for predicting the risk of CVD in these premenopausal women, however, these risk factors are insufficient in determining the impact and risk of CVD associated with hypoestrogenemia [5].

Animal research studies in cynomolgus monkeys have shown a strong correlation between hypoestrogenemia and pre-menopausal CVD [5]. These studies have observed that when young pre-menopausal cynomolgus monkeys are exposed to environmental stress (by continuous cage rotation and changes to social hierarchy), their stress response decreases ovarian stimulation leading to FHA-type characteristics [5]. These monkeys experience a decrease in FSH and LH levels and a subsequent decrease in their E2 levels leading to amenorrhea [5]. They also appear to develop CVDs related to atherosclerosis and abnormal coronary vasomotion [5]. Young pre-menopausal monkeys not exposed to the same environmental stresses are observed to maintain their normal ovarian function and estrogen levels and are subsequently observed to be protected from CVD [5]. Similarly, a self-report Nurses' Health Study with 82,000 women showed that the more irregular the menstrual cycle (amenorrheic), the greater the risk for CVDs [5]. Yet, few clinical research studies show the impact of hypoestrogenemia on $\mathrm{CV}$ outcomes in pre-menopausal women.

Exercise-associated amenorrhea (EAA), a reversible type of FHA, occurs in physically active women engaging in intense exercise coupled with nutritional deficiencies [7]. It is characterized by the abnormal pulsatility of FSH and LH leading to decreased levels of E2 and subsequent amenorrhea [7]. Depending on the intensity of exercise, $2-46 \%$ of athletic women experience secondary amenorrhea in contrast to $2-5 \%$ sedentary (non-exercising) women [8]. Although exercise has cardioprotective roles, when associated with chronic hypoestrogenism, the benefits can be trumped and can instead lead to negative impacts in $\mathrm{CV}$ functions [9]. However, there is a lack of research examining the effects of EAA on CVD outcomes in pre-menopausal women.

The purpose of this research proposal is to address the above knowledge gap by assessing the impact of EAA on CVD risk factors in athletic, pre-menopausal women. Specifically, this paper aims to address the influence of EAA on the levels of early CVD risk factors - NO, ET-1, and Eselectin - in athletic, pre-menopausal women. Additionally, this paper seeks to evaluate whether exogenous estrogen 
UNDERGRADUATE RESEARCH IN NATURAL AND CLINICAL SCIENCE AND TECHNOLOGY (URNCST) JOURNAL Read more URNCST Journal articles and submit your own today at: https://www.urnest.com

therapy can reverse the altered levels of these early CVD risk factors in athletic, amenorrheic women to the optimal range found in athletic, eumenorrheic (non-amenorrheic) women.

\section{$\underline{\text { Overview of Cardiovascular Risk Factors }}$}

Due to the lack of information on pre-menopausal amenorrheic athletes, data from post-menopausal women have been used to indicate whether 17- $\beta$ estradiol impacts $\mathrm{CV}$ factors such as endothelial function, lipid profiles including low-density lipoprotein (LDL), high-density lipoprotein (HDL) and total cholesterol (TC), susceptibility to lipid peroxidation, C-reactive protein (CRP), circulating nitrates, endothelin, and E-selectin levels [10]. The results are extrapolated and applied to amenorrheic athletes to predict whether estrogen deficiency can cause detrimental effects on the CV system in pre-menopausal, athletic women. The following are the traditional and early CVD risk factors that can be measured to evaluate the CVD risk of hypoestrogenism.

\section{Traditional CVD Risk Factors \\ 1. Lipid Profiles}

Cholesterol has many positive roles in the body. It is required for cell membrane stiffness and impermeability to water and ions and is the precursor for bile acids which are required to absorb lipids, aiding in digestion [11]. It is also the precursor for all steroid hormones including E2 and progesterone [11]. However, serum TC levels above 5.18 $\mathrm{mmol} / \mathrm{L}$ is considered as a general risk factor for coronary heart disease. TC levels tend to be increased in postmenopausal women, which can be due to the natural aging process or E2 deficiency [12]. One study showed elevated (>5.18 mmol/L) TC in amenorrheic women compared to eumenorrheic women [13]. Since saturated fat has a positive correlation with serum TC and unsaturated fat has a negative correlation with serum TC, diet can severely alter TC observations [14]. Moreover, the key role of LDL is to transport cholesterol to cells that require it [15], however levels above $3.37 \mathrm{mmol} / \mathrm{L}$ are an independent risk factor for developing CVDs [16], as it is associated with poor flowmediated dilation [17]. Normally, E2 has a cardioprotective effect on lipid levels by increasing the catabolic rate of hepatic cholesterol into bile [18] and increasing LDL receptors on cells to remove excess cholesterol from the blood [19]. Some studies show that LDL levels are elevated and are more atherogenic in post-menopausal women as the particles are denser and smaller [20], while LDL receptors are decreased due to hypoestrogenism [21]. However, in amenorrheic athletes versus eumenorrheic athletes, alterations in LDL levels are not clear as some studies show increased LDL while some show no statistical difference in their LDL levels. Furthermore, the amount of LDL greatly varies with type of diet [22]. In contrast, HDL is known to be anti-atherogenic as it delivers excess cholesterol from the blood to the liver for recycling [15] as well as displays antithrombotic behaviour. Additionally, HDL supports favourable vascular tone and decreases the oxidation of LDL [23]. In post-menopausal women, HDL levels were decreased [24]. There are variable findings for premenopausal, amenorrheic versus eumenorrheic athletes, indicating the unlikelihood of a single risk factor and demonstrating that E2-independent mechanisms can also lead to an increase in HDL [25].

\section{Lipid Peroxidation}

Reactive oxygen species (ROS) is produced as a natural by-product of metabolism. Therefore, exercise will cause greater increases in the production of ROS [26]. Oxidative stress occurs when there is an overproduction of ROS without enough antioxidants present to neutralize them, leading to oxidative damage to tissues and DNA [26]. Lipid peroxidation through the action of ROS increases the chance of developing atherosclerosis [27]. E2 can behave as an antioxidant and raise the levels of another antioxidant called glutathione peroxidase, and hence, may protect against atherosclerosis [28]. Research surrounding lipid peroxidation in post-menopausal women has been inconsistent [29], so this is an area of research that should be further explored. It was observed that there is a greater decrease in the ability for LDL to resist peroxidation in amenorrheic athletes compared to eumenorrheic athletes despite increased levels of antioxidants like glutathione peroxidase [30]. Discrepancies may have existed due to different levels of training [31], and so the correlation between hypoestrogenism and antioxidant status is unclear.

\section{C-Reactive Protein (CRP)}

Inflammation is usually associated with increased serum concentrations of CRP [32], which is a strong risk factor for developing CVD [33] and a good predictor for future cardiovascular events like strokes [34]. In healthy individuals, plasma CRP is under $3 \mathrm{mg} / \mathrm{L}$, however, it can be increased by several hundred times during bacterial infections or inflammatory diseases, prolonged exercise, smoking, age, and BMI [35]. No studies have reported the effects of EAA on CRP levels [36], however, there are studies relating CRP levels with PCOS, a hormonal disorder characterized by irregular menstrual cycles, among other factors like obesity [37]. These studies demonstrate increased levels of CRP with PCOS [37]. Moreover, although hormone replacement therapy has been shown to increase CRP levels [38], it may be representative of a metabolic effect rather than an inflammatory effect [32]. More research needs to be conducted in this area.

\section{Early CVD Risk Factors}

\section{Nitric Oxide (NO)}

$\mathrm{NO}$ is a vasodilator that helps to maintain vascular homeostasis and inhibits platelet aggregation [39]. Impaired release of NO is linked with E2 deficiency and can lead to hypertension, diabetes, and coronary artery disease [39]. Many studies show that E2 increases endothelium-dependent 
UNDERGRADUATE RESEARCH IN NATURAL AND CLINICAL SCIENCE AND TECHNOLOGY (URNCST) JOURNAL Read more URNCST Journal articles and submit your own today at: https://www.urncst.com

flow-mediated vasodilation [40]. Therefore, reduced levels of circulating E2 impairs endothelial function [10], which is also associated with a decreased amount of circulating nitrate/nitrite [41]. The association between the amount of E2 and the availability of NO has been demonstrated by many studies [10, 42]. The release of NO from endothelial cells due to estrogen on a nongenomic level is a rapid process [42]. A study examined NO levels in amenorrheic athletes and observed decreased levels of plasma nitrate production in amenorrheic athletes compared to sedentary, eumenorrheic women [43], even though chronic aerobic exercise normally increases plasma [44] and urinary NO concentrations [45]. The speculation for this contradiction may be that NO decreases in amenorrheic athletes due to their lower concentration of E2 [43]. Data from the same amenorrheic athletes demonstrated that E2 is very important for vascular function, as the resumption of menses in these women after hormone replacement therapy restored endothelial function to the level of eumenorrheic women [46].

\section{Endothelin-1 (ET-1)}

There are three types of endothelin peptides, ET-1, endothelin 2 (ET-2), and endothelin 3 (ET-3) [47]. ET1 is normally produced by endothelial cells, and regulates angiogenesis, blood pressure, vascular remodeling, etcetera. It is antagonistic to NO and is vasoconstrictive. Therefore, high levels of ET-1 is associated with many CVDs such as atherosclerosis [47]. E2 has been shown to inhibit ET-1 gene expression, by interfering with the extracellular signalregulated kinase pathway through inhibiting NADPH oxidase and ROS generation [48]. ET-1 levels are elevated in post-menopausal women but are significantly reduced after six months of E2 therapy [49]. Another study showed that after just one month of treatment with E2 ( $2 \mathrm{mg} /$ day) in older post-menopausal women, ET-1 mediated arterial constriction was reduced compared to the placebo group [50]. This suggests that although it is known that chronic exercise induces a decrease in ET-1 levels, this may be hampered due to hypoestrogenism [51]. There are no studies to date that have looked at the ET-1 levels of premenopausal, amenorrheic athletes.

\section{E-Selectin}

Atherosclerosis results in endothelial dysfunction and cell adhesion molecules such as E-selectin contribute to the activation of endothelial cells, increasing the inflammatory response [52]. The expression of E-selectin increases with coronary heart diseases in post-menopausal women [52]. It has been found that E2 decreases E-selectin levels by downregulating its promoter [53]. Hence, it makes sense why estrogen therapy has been effective in reducing E-selectin in the serum of post-menopausal participants, consequently resulting in higher flow-mediated dilation [52]. Reduced Eselectin translates to improved endothelial function through a reduction in activated endothelial cells and therefore decreased inflammation. These results were obtained within 3 to 6 months of estrogen therapy but E-selectin reduction was sustained after 6 months of treatment in postmenopausal subjects [52].

Method
Subjects

Volunteers will be recruited based on their daily physical activity participation and dietary lifestyle through group-level selection. The inclusion criteria will be athletic women between the ages of 18 to 35 undergoing 6 to 8 hours of structured physical activity per week, with BMI between 18.5 to 24.5 . The exclusion criteria will consist of smokers, women on contraceptives, and women with pre-existing cardiovascular or respiratory health conditions, or who have a family history of these conditions. The diet of the participants will be recorded and controlled for statistically after obtaining results. The sample size will include 90 female athletes, with 45 of the participants having secondary amenorrhea and 45 with regular menstruation status.

\section{Subject Categorization}

Athletic women will be subdivided into two separate groups (45 women in each group) based on their menstrual status. Volunteers with stable menstrual cycles who experienced monthly periods regularly will be categorized as non-amenorrheic athletes. Meanwhile, secondary amenorrheic women (those who have experienced their first menses but have had unstable cycles following the initial cycle and have not gotten their last period for at least 3 consecutive months) will be grouped as amenorrheic athletes.

\section{Experimental Design}

This study (refer to Figure 2) will be segmented into preand post- estrogen treatment where the intervention (estrogen treatment) remains the same for the entirety of the 45 amenorrheic, athletic subjects while the non-amenorrheic subjects do not receive exogenous estrogen. The preestrogen therapy section of the study consists of measuring baseline levels for estrogen and the selected CVD risk factors, NO, ET-1, and E-selectin, in serum from all 90 participants. The obtained values will be compared between non-amenorrheic athletes and amenorrheic athletes. The tests that will be used to measure the E2 and CVD risk factors' levels will be duplicated to ensure accuracy.

The second segment of the study consists of the intervention, also known as the 17- $\beta$ estradiol treatment analysis, which applies only to the 45 amenorrheic participants. The intervention is the administration of exogenous estrogen to amenorrheic athletes at a standard concentration to match endogenous estrogen levels in nonamenorrheic athletes. During this intervention strategy, the concentrations of E2 and the three CVD risk factors will be measured in amenorrheic athletes through bi-weekly blood collection and subsequent serum analyses. These 


\section{UNDERGRADUATE RESEARCH IN NATURAL AND CLINICAL SCIENCE AND TECHNOLOGY (URNCST) JOURNAL}

Read more URNCST Journal articles and submit your own today at: https://www.urncst.com

concentrations will then be compared to the concentrations of E2 and the CVD risk factors obtained during the preintervention stage in amenorrheic and non-amenorrheic athletes.

The total timeline of the study is 7 months. Within the 7-month duration, the first month consists of baseline data collection, and months 2 through 7 is when exogenous estrogen administration takes place. Simultaneously, estrogen-treatment phase data collection will occur bi-weekly during months 2-7.

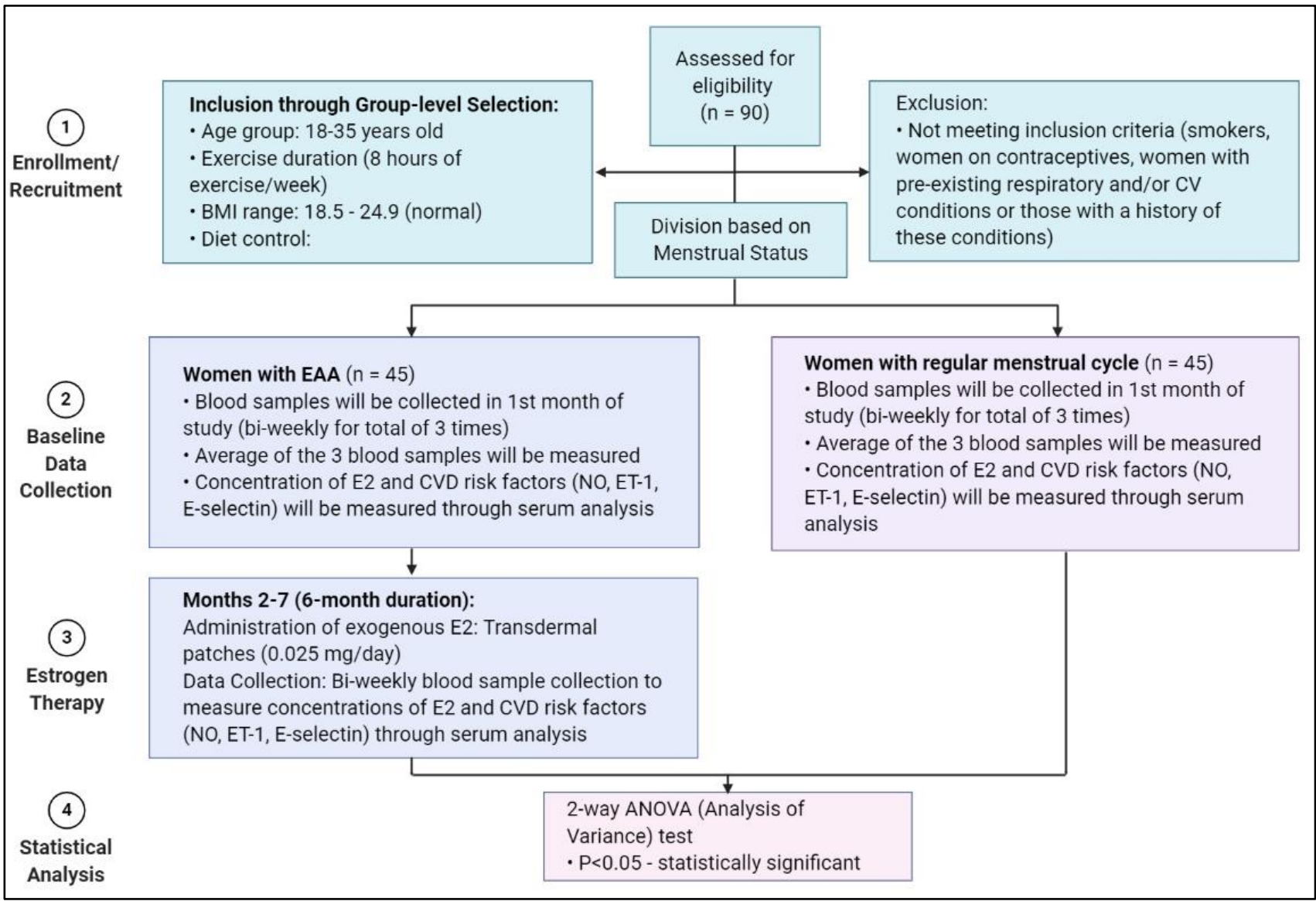

Figure 2. This figure outlines the experimental protocol proposed within this paper. Once athletic participants are assessed for eligibility, they will be categorized into amenorrheic or non-amenorrheic groups based on their menstrual status. Both groups will be tested for concentrations of E2 and the CVD risk factors (NO, ET-1, E-selectin) during the baseline data collection phase. The amenorrheic group will then proceed to the estrogen therapy phase which will run for 6 months, with bi-weekly blood sample collection to measure concentrations of E2 and CVD risk factors (as a time-course study). Statistical analyses using 2-way ANOVA will be performed on every data measurement obtained. Illustrated using BioRender.

\section{$\underline{\text { Baseline Data Collection - Serum Analysis }}$}

Blood samples will be collected from the participants prior to the estrogen therapy phase in the first month of the study, bi-weekly, for a total of three times. The three datasets will be averaged out to account for any alterations in E2 and the CVD risk factors' concentrations during the menstrual cycle. The serum samples collected from both amenorrheic and non-amenorrheic athletic participants will be analyzed through biological assays. The concentration of E2 and CVD risk factors from the serum samples of non-amenorrheic athletes will serve as the baseline data to compare to the data obtained from the amenorrheic, athletic subjects. Endothelin, $\mathrm{NO}$, and E-selectin concentrations will be determined from blood serum assays.

To test the E2 levels and the three early CVD risk factors, $4 \mathrm{~mL}$ of blood will be drawn for each test for a total blood volume of $16 \mathrm{~mL}$ for the 4 tests (refer to Figure 3). This will allow for a $1 \mathrm{~mL}$ serum volume (from every $4 \mathrm{~mL}$ of blood) to be obtained from the blood sample after centrifuging (refer to Figure 3). Replicate testing will be done by drawing a total of $32 \mathrm{~mL}$ of blood. 


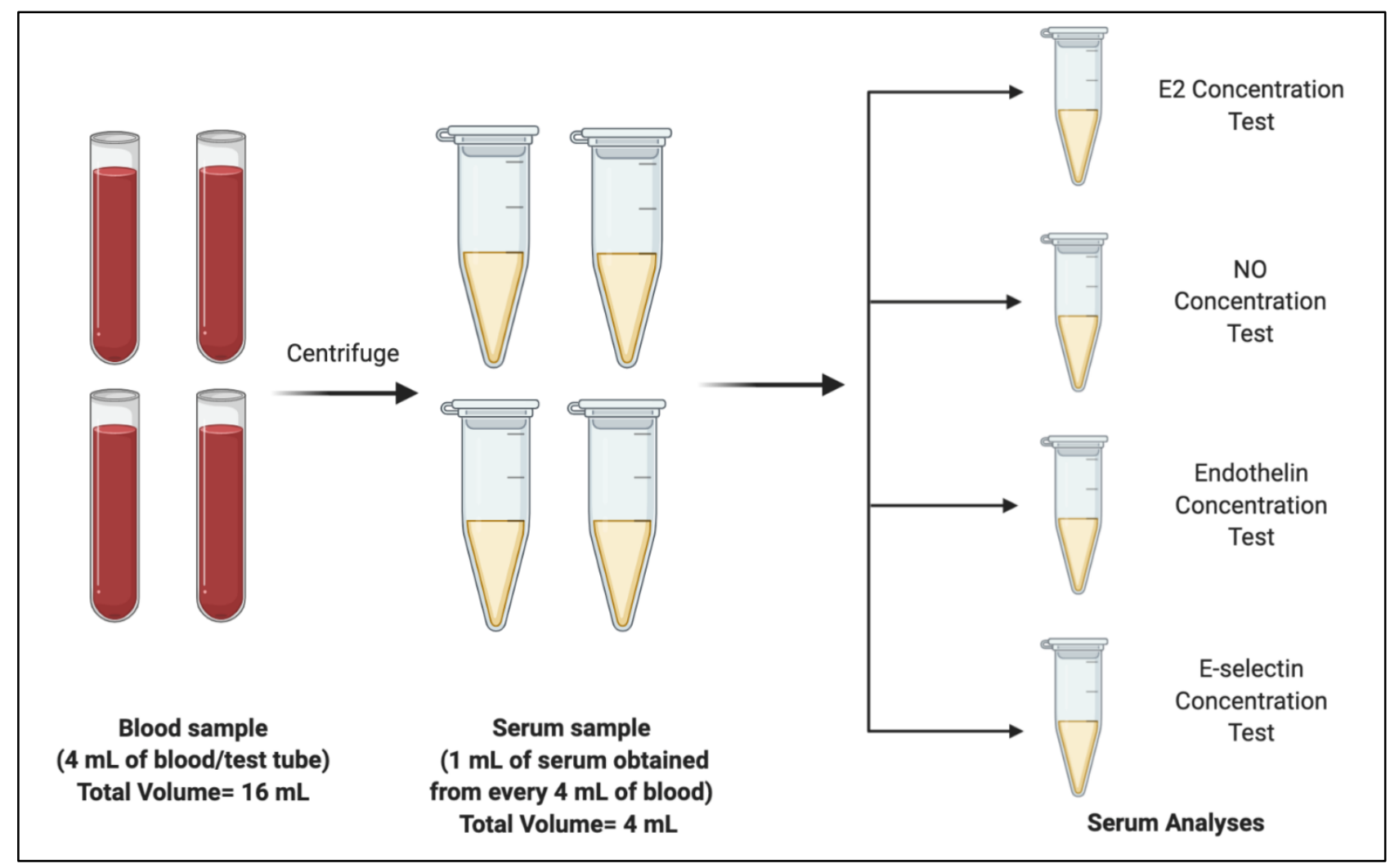

Figure 3. A visual representation of the collection, allocation and analysis of blood samples obtained from participants. During each collection stage, a total of $16 \mathrm{~mL}$ of blood will be collected to allow for $1 \mathrm{~mL}$ of serum to be obtained (after centrifugation) from every $4 \mathrm{~mL}$ of blood. The obtained serum will then undergo testing for concentrations of E2 and CVD risk factors. These tests will be replicated at each stage. Illustrated using BioRender.

\section{Estrogen Therapy}

Exogenous E2 will be administered to amenorrheic, athletic subjects transdermally using estrogen patches. The patches will provide a daily dosage of $0.025 \mathrm{mg}$ of $17-\beta$ estradiol to the participants for a duration of 6 months from months 2-7 of the study.

\section{Treatment Phase Data Collection - Serum Analysis}

Serum samples will be taken from the 45 amenorrheic, athletes (all of whom will have received a standard E2 dosage during the estrogen therapy phase) through blood collection. Estrogen, endothelin, NO, and E-selectin concentrations will be determined from blood serum assays (using the same blood sample collection method mentioned above; Figure 3). Blood will be drawn bi-weekly during months 2-7 of the study (refer to Figure 2).

\section{Statistical Methods}

Statistical analysis will be conducted to compare the levels of E2 and the CVD risk factors prior to and following estrogen treatment of amenorrheic, athletic subjects and will be used to identify trends in these factors as a result of E2 administration. The main statistical method used will consist of 2-way ANOVA with the non-amenorrheic or amenorrheic state of subjects being the two independent variables and the $\mathrm{CV}$ factor levels serving as the dependent variable. Results of the two-way ANOVA will be interpreted under the premise of $\mathrm{P}<0.05$ being considered statistically significant (refer to Figure 2).

\section{Discussion}

The purpose of this proposed research is to look at the effects of EAA on levels of E2 and early CVD risk factors such as NO, ET-1, and E-selectin in athletic, pre-menopausal women. Subsequently, this research proposal aims to examine the impact of exogenous estrogen treatment on concentrations of E2 and early CVD risk factors in participants with EAA. The following discussion will highlight the expected results of the proposed research experiment using previous studies on post-menopausal women with similar E2 deficiency levels as those with EAA. The discussion will then detail the reasoning behind the methodological decisions made and conclude with the clinical relevance of estrogen therapy and its implications.

\section{Anticipated Results}

Prior to estrogen therapy, the NO concentrations of participants with EAA would be lower compared to the non- 
UNDERGRADUATE RESEARCH IN NATURAL AND CLINICAL SCIENCE AND TECHNOLOGY (URNCST) JOURNAL Read more URNCST Journal articles and submit your own today at: https://www.urncst.com

amenorrheic athletes. However, following estrogen therapy, the NO concentrations in the serum samples of amenorrheic athletic participants is expected to increase. This is due to the association between reduced E2 levels and disrupted endothelial function through reduced nitrate/nitrite levels $[10,43]$. Therefore, an opposing relationship between E2 and nitrate/nitrite is expected with estrogen surges via exogenous estrogen therapy. Contrasting NO, endothelin is vasoconstrictive [47]. Endothelin peptides, specifically ET-1 are increased post-menopause which is considered a hypoestrogenic state [49]. Studies have shown that endothelin concentrations in post-menopausal women have the potential to be reduced following E2 therapy [49]. Therefore, the findings of ET-1 levels can be extrapolated from the postmenopausal women to predict that ET-1 would be elevated in amenorrheic athletes and are expected to decrease upon treatment with exogenous estrogen. Furthermore, E-selectin is yet another early CVD risk factor that is increased in postmenopausal women but can be reduced with the help of estrogen therapy [52]. Therefore, it is expected of amenorrheic athletic participants to have elevated E-selectin levels prior to E2-treatment and reduced concentrations of Eselectin following exogenous estrogen therapy.

\section{Methodological Considerations}

\section{Participants' Age and Menstrual Status}

Participants were chosen based on the age range of 18-35 because the target subjects of the research protocol are pre-menopausal athletes. Since menopause usually occurs after the age of 45 , by choosing the age range of 18-35, selection of pre-menopausal women is likely [5]. Additionally, secondary amenorrheic participants were chosen over primary amenorrheic ones because functional hypothalamic amenorrhea - under which EAA falls - is a form of secondary amenorrhea as opposed to primary amenorrhea [5]. Moreover, most studies have been conducted on endurance athletes with EAA [10] as they are more likely to develop EAA without sufficient nutritional intake [7]. For this reason, the participants will be endurance athletes (for example, participating in competitive swimming or cycling). To control for their activity levels, the athletes must be exercising 6 to 8 hours a week because if the average person exercises 30 minutes per day, it can be approximated that people training for more endurance sports would exercise at least 6 to 8 hours a week to train. To control for BMI's influence on concentrations of CVD risk factors, participants with BMI between the range of 18.5 to 24.5 will be selected, which is considered to be the normal, healthy weight [54].

\section{Experimental Design and Selection of Cardiovascular Risk} Factors

This experiment is a 2-part study where, before the estrogen intervention, the baseline levels of the CVD risk factors (NO, ET-1, and E-selectin) and estrogen in nonamenorrheic women will be determined and compared to the levels of these same CVD risk factors and estrogen in participants with EAA. The purpose of including this crosssectional method before conducting the actual intervention is because there is a lack of research evaluating the levels of the selected CVD risk factors in pre-menopausal women with EAA. Before this study, data would have to be extrapolated from post-menopausal women and applied to pre-menopausal women.

When determining the risks of hypoestrogenism on $\mathrm{CV}$ health, studies on post-menopausal women have looked at traditional markers of $\mathrm{CV}$ health such as lipid profiles and CRP levels. There is a high variability in the levels of TC, LDL, and HDL in amenorrheic athletes versus eumenorrheic (non-amenorrheic) athletes or even in post-menopausal women, due to their immediate susceptibility to dietary intake and other possible confounding factors [14,22,25]. CRP levels can also increase due to many factors such as infections, diet, and prolonged exercise [35]. Hence, it is difficult to come to any conclusion about the risk for CVD in patients with EAA using these markers and thus, they are not included in the proposed research protocol. In order to assess lipid peroxidation due to exercise, either free radicals, damage to lipids, or the amount of antioxidants would need to be measured during and after exercise. Due to the extra step, this method is more complicated than using other markers, and will not be used in the proposed experimental protocol.

In comparison, NO, ET-1, and E-selectin are selected as CVD markers for this experimental protocol as there are not as many acute, confounding factors as there are for the traditional markers mentioned above. Furthermore, since a common pathophysiological feature in many CVDs is endothelial dysfunction [55], it could be speculated that NO and ET-1 allow for earlier detection of CVD risk. Since Eselectin has a role in the initiation of the inflammatory process, it may also allow for early detection of CVD risk [56]. Another benefit of using NO specifically is that it responds quickly to E2 [42]. Since E2 impacts both ET-1 and E-selectin through genomic regulation $[48,53]$, changes may be delayed, hence the longer time course of the experimental protocol (detailed in the next section). As there is insufficient research available to determine how long it will take to see these genomic changes, this study will also serve as a timecourse experiment for determining when significant changes in the concentrations of the early CVD risk factors occur.

\section{Timeline of Study}

A total duration of 7 months will be chosen for the timeline of the study because the concentrations of the chosen CVD risk factors such as NO respond quickly to estrogen presence [55]. A 7-month study duration also allows the experimental protocol to be more practical than a longer-term study. Additionally, it can be speculated that the levels of the CVD risk factors will respond to estrogen therapy more rapidly in pre-menopausal women and will require a shorter duration compared to the time it takes for 
UNDERGRADUATE RESEARCH IN NATURAL AND CLINICAL SCIENCE AND TECHNOLOGY (URNCST) JOURNAL Read more URNCST Journal articles and submit your own today at: $\underline{\text { htps://www.urncst.com }}$

estrogen therapy to be effective in post-menopausal women [57].

Bi-weekly blood sample collection during the baseline phase will be done to account for changes in E2 and early CVD risk factors (NO, ET-1, E-selectin) during the monthly ovulatory cycle. Bi-weekly blood sample collection during the E2-treatment phase will also be done, as a time-course study, to identify when significant changes in the concentrations of CVD risk factors occur.

\section{Analysis of E2 and Early CVD Risk Factors}

For data collection during both the baseline and E2 therapy phases, the concentration of E2 and the early CVD risk factors (NO, endothelin, E-selectin) in the cardiovascular system will be determined through serum analysis of the blood samples collected from participants. To run analysis tests, $16 \mathrm{~mL}$ of blood will be drawn to account for $4 \mathrm{~mL}$ of blood per test of E2 and each CVD risk factor (refer to Figure 3). Each blood sample will then be centrifuged to obtain $1 \mathrm{~mL}$ of serum sample for each test of E2 and CVD risk factors (refer to Figure 3). During every blood collection stage, a total of $32 \mathrm{~mL}$ of blood will be drawn from each participant to ensure that replicate testing for E2 and each CVD risk factor can be performed.

Although this is an invasive data collection method, serum samples are more reliable than urine samples as concentration of E2 and the early CVD risk factors in urine may also be subjected to inputs from the digestive system [58]. Moreover, serum samples offer more stability as they are capable of being refrigerated and can undergo 1-3 freeze/thaw cycles with minimal effects on metabolite concentrations in contrast to urine samples [58]. Hence, serum analysis is a more stable and reliable measure that will allow for determining the concentration of E2 and the early CVD risk factors in the cardiovascular (arterial) system.

\section{Administration of $17 \beta$-Estradiol}

For estrogen therapy, E2 has been chosen over the administration of other forms of estrogens (for example, conjugated equine estrogens) as E2 is structurally identical to the estradiol produced and secreted by human ovaries [59]. Although exogenous estrogen preparations are available in many forms including oral preparations, the proposed experimental protocol utilizes a transdermal patch to administer the E2 to amenorrheic, pre-menopausal participants. Compared to transdermal patches, oral preparations of exogenous estrogen require a higher dosage $(0.5-1 \mathrm{mg} / \mathrm{day})$ to be given to the amenorrheic patient to ensure its bioavailability as it is metabolized by the liver [60]. Moreover, due to the high dosage required for oral estrogens, their administration must be avoided in women with hypertriglyceridemia or thrombophilias to prevent any potential clotting [59]. In comparison, transdermal patches require a lower dosage $(0.025 \mathrm{mg} / \mathrm{day})$ to be administered and can be used for women with the above-mentioned risks and is also recommended for women diagnosed with migraine headaches with auras [59]. Hence, this study utilizes transdermal patches as a method to administer safe doses of exogenous estrogens to athletic, pre-menopausal women. As such, a standard estrogen dosage of 0.025 $\mathrm{mg} /$ day for the transdermal patch is chosen for this experimental protocol to ensure that the dose has a low risk of clotting (coagulation), stroke and inflammation occurrences in the participants [59].

\section{Clinical Benefits and Risks of Estrogen Therapy}

Estrogen therapy is a helpful therapy for amenorrheic women, specifically those with functional hypothalamic amenorrhea (FHA) [5], but it must be weighed against its potential risk. Estrogen therapy results in the resumption of menses and can prevent further damage to bones and cardiovascular health that would occur due to estrogen deficiency [5]. However, one major shortcoming of exogenous estrogen is its incapability to reset endogenous estrogen back to normal levels in the long-term [5]. In the case of FHA and its many types, treating the biological root of the condition cannot be achieved through estrogen therapy [5]. Other forms of hormone therapy such as human menopausal gonadotropin to address the infertility side effects associated with amenorrhea can cause ovulation but bear the possibility of numerous pregnancies and hyperstimulation syndrome [5]. Other than estrogen's cardioprotective role, estrogen replacement therapy for the treatment of EAA has been shown to upregulate bone density in amenorrheic athletes compared to amenorrheic runners not receiving the therapy who experienced bone density reductions [61]. However, estrogen's positive influence on bone density is immediately lost with the discontinuation of hormone replacement therapy [5]. Additionally, the risks of exogenous hormone administration in older subjects $(>60$ years of age) outweigh the benefits of bone protection and is therefore not a viable treatment option [62]. The risks of the various forms of estrogen therapy for post-menopausal women include, but are not limited to, the increased chance of stroke, relapse of breast cancer as well as endometrial hyperplasia [59]. Yet, there are advantages to estrogen therapy in peri- and post-menopausal ages, which consists of reducing the occurrence of hot flashes, ameliorating reproductive function and aiding with the manifestations of genitourinary syndrome of menopause [59]. As evident, there exists a plethora of risks and benefits to estrogen therapy, but the disadvantages are mainly towards post-menopausal women taking exogenous estrogen and are therefore less clinically relevant to the participants of this research proposal.

\section{Conclusions}

The aim of this research proposal is to evaluate the influence of E2 deficiency on CVD outcomes in athletic, premenopausal women with EAA, and to determine whether estrogen therapy can help return the levels of the early CVD risk factors back to optimal levels. Participants of this experimental protocol will include pre-menopausal athletes 
UNDERGRADUATE RESEARCH IN NATURAL AND CLINICAL SCIENCE AND TECHNOLOGY (URNCST) JOURNAL Read more URNCST Journal articles and submit your own today at: https://www.urncst.com

with hypoestrogenism, who engage in weekly physical activity, as their hypoestrogenic status manifests into increased risk of CVD development. Amenorrheic, premenopausal athletes are postulated to have decreased NO levels, increased ET-1, and increased E-selectin concentrations - all of which are considered early CVD risk factors and are associated with estrogen deficiency. Therefore, diagnosis and management of menstrual irregularities such as EAA is critical for cardiovascular health and early prevention of CVD.

Even though this research proposal does not aim to provide a long-term solution for EAA, more research studies should be conducted to determine whether estrogen therapy can be used as a long-term solution to restore menstrual function for women with EAA, or whether it can help sustain $\mathrm{CV}$ health in women with EAA through life-long use of E2 therapy through maintenance dosages.

With the help of this research, medical professionals can place more emphasis on the long-term health consequences that stem from hypoestrogenism apart from reproductive function - such as cardiovascular health. By determining alterations in levels of early CVD risk factors (NO, ET-1, Eselectin) as a result of E2 deficiency, impairments of the cardiovascular system can be detected earlier, leading to better prognosis.

Future research can be directed towards assessment of the long-term influence of E2 deficiency and subsequent E2 therapy on CVD risk factors on a genomic level. Another future direction is to see whether selecting a diet to help premenopausal women manage their EAA along with hormone replacement therapy can provide a potential treatment for EAA. Other research experiments can also include a larger sample size to observe whether similar results are obtained. Lastly, more research is needed to evaluate the potential of these CVD risk factors as biomarkers for early detection of CVDs in women with EAA.

\author{
List of Abbreviations \\ ANOVA: Analysis of Variance \\ BMI: body mass index \\ CRP: C-reactive protein \\ CV: cardiovascular \\ CVD: cardiovascular disease \\ E2: $17 \beta$-estradiol (ovarian hormone) \\ EAA: exercise-associated amenorrhea \\ ET-1: endothelin-1 \\ FHA: functional hypothalamic amenorrhea \\ FSH: follicle-stimulating hormone \\ GnRH: gonadotropin-releasing hormone \\ HDL: high-density lipoprotein \\ LDL: low-density lipoprotein \\ LH: luteinizing hormone \\ NO: nitric oxide \\ ROS: reactive oxygen species \\ TC: total cholesterol
}

\section{Conflicts of Interest}

The authors declare that they have no conflict of interests.

\section{Ethics Approval and/or Participant Consent}

Ethics approval from the Hamilton Integrated Research Ethics Board (HiREB) will be sought. Participants will be provided with the experiment design and the opportunity to ask any questions prior to the experimental study. They will also sign an approved consent form to confirm their informed consent to participating in this study.

\section{Authors' Contributions}

NSA: made substantial contributions to study design, collection, analysis \& interpretation of data from studies, drafted and revised the manuscript, gave final approval for recent version to be published, agreed upon responsibility concerned with accuracy and integrity of the work.

PL: made substantial contributions to study design, collection, analysis \& interpretation of data from studies, drafted and revised the manuscript, gave final approval for recent version to be published, agreed upon responsibility concerned with accuracy and integrity of the work.

AE: made substantial contributions to study design, collection, analysis \& interpretation of data from studies, drafted and revised the manuscript, gave final approval for recent version to be published, agreed upon responsibility concerned with accuracy and integrity of the work.

\section{Acknowledgements}

We would like to acknowledge and thank our supervisor, Jennifer Williams (MSc), for mentoring and supporting us through our journey. We would also like to thank the URNCST team for this opportunity.

\section{Funding}

This study was not funded.

\section{References}

[1] Cho L, Davis M, Elgendy I, Epps K, Lindley KJ, Mehta PK, et al. Summary of Updated Recommendations for Primary Prevention of Cardiovascular Disease in Women: JACC State-of-theArt Review. Journal of the American College of Cardiology. 2020 May 26;75(20):2602-18. https://doi.org/10.1016/j.jacc.2020.03.060

[2] Heart and Stroke. Ms.Understood: Women's hearts are victims of a system that is ill-equipped to diagnose, treat and support them. Heart \& Stroke 2018 Heart Report [Internet]. 2018 [cited 2020 Sep 23]. Available from: https://www.heartandstroke.ca/-/media/pdf-files/ canada/2018-heart-month/hs_2018-heart-report_en. ashx?rev=71bed5e2bcf148b4a0bf5082e50de6c6

[3] Aryan L, Younessi D, Zargari M, Banerjee S, Agopian J, Rahman S, et al. The Role of Estrogen Receptors in Cardiovascular Disease. International Journal of 
UNDERGRADUATE RESEARCH IN NATURAL AND CLINICAL SCIENCE AND TECHNOLOGY (URNCST) JOURNAL Read more URNCST Journal articles and submit your own today at: https://www.urncst.com

Molecular Sciences. 2020 June 17;21(12):4314. https://doi.org/10.3390/ijms21124314

[4] O'Donnell E. Cardiovascular Consequences of Estrogen Deficiency: Studies in Pre-menopausal Women [dissertation on the Internet]. Graduate Department of Exercise Sciences: University of Toronto; 2013 [cited 2020 Sep 23]. Available from: https://tspace.library.utoronto.ca/bitstream/1807/43692 13/O\%27Donnell_Emma_201311_PhD thesis.pdf

[5] Shufelt CL, Torbati T, Dutra E. Hypothalamic Amenorrhea and the Long-Term Health Consequences. Seminars in Reproductive Medicine. 2017 May;35(3):256-62. https://doi.org/10.1055/s-00371603581

[6] Roberts RE, Farahani L, Webber L, Jayasena C. Current understanding of hypothalamic amenorrhoea. Therapeutic Advances in Endocrinology. 2020 July 30;11:1-12. https://doi.org/10.1177/2042018820945854

[7] Warren MP. Health Issues for Women Athletes: Exercise-Induced Amenorrhea. The Journal of Clinical Endocrinology \& Metabolism. 1999 Jun 1;84(6):18926. https://doi.org/10.1210/jcem.84.6.5806

[8] O’Donnell E, Goodman JM, Harvey PJ. Cardiovascular Consequences of Ovarian Disruption: A Focus on Functional Hypothalamic Amenorrhea in Physically Active Women. The Journal of Clinical Endocrinology \& Metabolism. 2011 Dec 1;96(12):3638-48. https://doi.org/10.1210/jc.2011-1223

[9] O’Donnell E, Harvey PJ, Goodman JM, De Souza MJ. Long-term estrogen deficiency lowers regional blood flow, resting systolic blood pressure, and heart rate in exercising pre-menopausal women. American Journal of Physiology-Endocrinology and Metabolism. 2007 January 16;292(5):1401-9. https://doi.org/10.1152/ajpendo.00547.2006

[10] O’Donnell E, De Souza MJ. The Cardiovascular Effects of Chronic Hypoestrogenism in Amenorrhoeic Athletes: A Critical Review. Sports Medicine. 2012 Sep 4;34(9):601-27. https://doi.org/10.2165/00007256200434090-00004

[11] Cortés V, Busso D, Mardones P, Maiz A, Arteaga A, Nervi F, Rigotti A. Advances in the physiological and pathological implications of cholesterol. Biological Reviews. 2013 Jan 6;88:825-43. https://doi.org/10.1111/brv.12025

[12] Urabe M, Yamamoto T, Kashiwagi T, Okubo T, Tsuchiya H, Iwasa K, Kikuchi N, Yokota K, Hosokawa $\mathrm{K}$, Honjo H. Effect of estrogen replacement therapy on hepatic triglyceride lipase, lipoprotein lipase and lipids including apolipoprotein $\mathrm{E}$ in climacteric and elderly women. Endocrine Journal. 1996;43(6):737-42. https://doi.org/10.1507/endocrj.43.737

[13] Irons BK, Snella KA, McCall K, MacLaughlin EJ, Villarreal M. Update on the management of dyslipidemia. American Journal of Health-System
Pharmacy. 2002 Sep 1;59(17):1615-25. https://doi.org/ 10.1093/ajhp/59.17.1615

[14] Dietschy JM. Dietary fatty acids and the regulation of plasma low density lipoprotein cholesterol concentrations. The Journal of Nutrition. $1998 \mathrm{Feb}$ 1;128(2):444S-8S. https://doi.org/10.1093/jn/128.2.444S

[15] The role of cholesterol [Internet]. [cited 2020 Dec 28]. Available from: https://www.independentnurse.co.uk/ clinical-article/the-role-of-cholesterol/63612/

[16] Expert Panel on Detection E. Executive summary of the third report of the National Cholesterol Education Program (NCEP) expert panel on detection, evaluation, and treatment of high blood cholesterol in adults (Adult Treatment Panel III). Jama. 2001 May 16;285(19):2486-97. https://doi.org/10.1001/jama.285.19.2486

[17] O’Connell BJ, Genest Jr J. High-density lipoproteins and endothelial function. Circulation. 2001 Oct 16;104(16):1978-83. https://doi.org/10.1161/hc3901 .096667

[18] Kushwaha RS, Lewis DS, Carey KD, McGill Jr HC. Effects of estrogen and progesterone on plasma lipoproteins and experimental atherosclerosis in the baboon (Papio sp.). Arteriosclerosis and Thrombosis: A Journal of Vascular Biology. 1991 Jan;11(1):23-31. https://doi.org/10.1161/01.ATV.11.1.23

[19] Parini P, Angelin B, Rudling M. Importance of estrogen receptors in hepatic LDL receptor regulation. Arteriosclerosis, Thrombosis, and Vascular Biology. 1997 Sep 1;17(9):1800-5. https://doi.org/10.1161/ 01.ATV.17.9.1800

[20] Barrett-Connor EL. Testosterone and risk factors for cardiovascular disease in men. Diabete \& Metabolisme. 1995 May 31;21(3):156-61. Available from: https://pubmed.ncbi.nlm.nih.gov/7556805/

[21] Roeters van Lennep JE, Westerveld HT, Erkelens DW, van der Wall EE. Risk factors for coronary heart disease: implications of gender. Cardiovascular Research. 2002 Feb 15;53(3):538-49. https://doi.org/10.1016/s0008-6363(01)00388-1

[22] Akahoshi M, Soda M, Nakashima E, Tsuruta M, Ichimaru S, Seto S, Yano K. Effects of age at menopause on serum cholesterol, body mass index, and blood pressure. Atherosclerosis. 2001 May 1;156(1):157-63. https://doi.org/10.1016/s00219150(00)00609-2

[23] Saku K, Ahmad M, Glas-Greenwalt P, Kashyap ML. Activation of fibrinolysis by apolipoproteins of high density lipoproteins in man. Thrombosis Research. 1985 Jul 1;39(1):1-8. https://doi.org/10.1016/00493848(85)90116-1

[24] Suda Y, Ohta H, Makita K, Takamatsu K, Horiguchi F, Nozawa S. Influence of bilateral oophorectomy upon lipid metabolism. Maturitas. 1998 Jun 3;29(2):147-54. https://doi.org/10.1016/S0378-5122(97)00089-3 
UNDERGRADUATE RESEARCH IN NATURAL AND CLINICAL SCIENCE AND TECHNOLOGY (URNCST) JOURNAL Read more URNCST Journal articles and submit your own today at: https://www.urncst.com

[25]Zmuda JM, Yurgalevitch SM, Flynn MM, Bausserman LL, Saratelli A, Spannaus-Martin DJ, Herbert PN, Thompson PD. Exercise training has little effect on HDL levels and metabolism in men with initially low HDL cholesterol. Atherosclerosis. 1998 Mar 3;137(1):215-21. https://doi.org/10.1016/S00219150(97)00257-8

[26] He F, Li J, Liu Z, Chuang C-C, Yang W, Zuo L. Redox Mechanism of Reactive Oxygen Species in Exercise. Frontiers in Physiology. 2016 Nov 7;486(7):1-10. https://doi.org/10.3389/fphys.2016.00486

[27] Negre-Salvayre A, Auge N, Ayala V, Basaga H, Boada J, Brenke R, et al. Pathological aspects of lipid peroxidation. Free Radical Research. 2010 Oct $1 ; 44(10): 1125-71$ https://doi.org/10.3109/10715762.2010.498478

[28] Akova B, SuÈrmen-GuÈr E, Gǜr H, Dirican M, SarandoÈl E, Küçükoglu S. Exercise-induced oxidative stress and muscle performance in healthy women: role of vitamin E supplementation and endogenous oestradiol. European Journal of Applied Physiology. 2001 Feb 1;84(1-2):141-7. https://doi.org/10.1007/s004210000331

[29] Bureau I, Laporte F, Favier M, Faure H, Fields M, Favier AE, Roussel AM. No antioxidant effect of combined HRT on LDL oxidizability and oxidative stress biomarkers in treated post-menopausal women. Journal of the American College of Nutrition. 2002 Aug $1 ; 21(4): 333-8$. https://doi.org/10.1080/07315724.2002.10719231

[30] Ayres S, Baer J, Subbiah MR. Exercised-induced increase in lipid peroxidation parameters in amenorrheic female athletes. Fertility and Sterility. 1998 Jan 1;69(1):73-7. https://doi.org/10.1016/s00150282(97)00428-7

[31] Palazzetti S, Richard MJ, Favier A, Margaritis I. Overloaded training increases exercise-induced oxidative stress and damage. Canadian Journal of Applied Physiology. 2003 Aug 1;28(4):588-604. https://doi.org/10.1139/h03-045

[32] Silvestri A, Gebara O, Vitale C, Wajngarten M, Leonardo F, Ramires JA, Fini M, Mercuro G, Rosano GM. Increased levels of C-reactive protein after oral hormone replacement therapy may not be related to an increased inflammatory response. Circulation. 2003 Jun 9;107(25):3165-9. https://doi.org/10.1161/01.CIR. $\underline{0000074208.02226 .5 \mathrm{E}}$

[33] Ridker PM, Hennekens CH, Buring JE, Rifai N. Creactive protein and other markers of inflammation in the prediction of cardiovascular disease in women. New England Journal of Medicine. 2000 Mar 23;342(12):836-43. https://doi.org/10.1056/NEJM200003233421202

[34] Blake GJ, Ridker PM. C-reactive protein, subclinical atherosclerosis, and risk of cardiovascular events. Arteriosclerosis, Thrombosis, and Vascular Biology.
2002 Oct 1;22:1512-1513. https://doi.org/10.1161/ 01.ATV.0000038145.59548.85

[35] Fallon KE, Fallon SK, Boston T. The acute phase response and exercise: court and field sports. British Journal of Sports Medicine. 2001 Jun 1;35(3):170-3. https://doi.org/10.1136/bjsm.35.3.170

[36] Mattusch F, Dufaux B, Heine O, Mertens I, Rost R. Reduction of the plasma concentration of C-reactive protein following nine months of endurance training. International Journal of Sports Medicine. 2000 Jan;21(01):21-4. https://doi.org/10.1055/s-2000-8852

[37] Boulman N, Levy Y, Leiba R, Shachar S, Linn R, Zinder O, et al. Increased C-Reactive Protein Levels in the Polycystic Ovary Syndrome: A Marker of Cardiovascular Disease. The Journal of Clinical Endocrinology \& Metabolism. 2004 May 1;89(5):2160 5. https://doi.org/10.1210/jc.2003-031096

[38] Barinas-Mitchell E, Cushman M, Meilahn EN, Tracy RP, Kuller LH. Serum Levels of C-reactive Protein Are Associated with Obesity, Weight Gain, and Hormone Replacement Therapy in Healthy Post-menopausal Women. American Journal of Epidemiology. 2001 Jun 1;153(11):1094-101. https://doi.org/10.1093/aje/153.11.1094

[39] Tousoulis D, Kampoli AM, Tentolouris Nikolaos Papageorgiou C, Stefanadis C. The Role of Nitric Oxide on Endothelial Function. Current Vascular Pharmacology. 2012 Jan 1;10(1):4-18. https://doi.org/10.2174/157016112798829760

[40] Gerhard M, Walsh BW, Tawakol A, Haley EA, Creager SJ, Seely EW, Ganz P, Creager MA. Estradiol therapy combined with progesterone and endotheliumdependent vasodilation in postmenopausal women. Circulation. 1998 Sep 22;98(12):1158-63. https://doi.org/10.1161/01.CIR.98.12.1158

[41] Rosselli M, Imthurn B, Keller PJ, Jackson EK, Dubey RK. Circulating nitric oxide (nitrite/nitrate) levels in postmenopausal women substituted with $17 \beta$-estradiol and norethisterone acetate: a two-year follow-up study. Hypertension. 1995 Apr 1;25(4):848-53. https://doi.org/ 10.1161/01.HYP.25.4.848

[42] Nevzati E, Shafighi M, Bakhtian KD, Treiber H, Fandino J, Fathi AR. Estrogen Induces Nitric Oxide Production Via Nitric Oxide Synthase Activation in Endothelial Cells. In: Fandino J, Marbacher S, Fathi AR, Muroi C, Keller E, editors. Neurovascular Events After Subarachnoid Hemorrhage: Towards Experimental and Clinical Standardisation [Internet]. Cham: Springer International Publishing; 2015 [cited 2020 Dec 29]. p. 141-5. (Acta Neurochirurgica Supplement). https://doi.org/10.1007/978-3-319-04981-6_24

[43] Stacey E, Korkia P, Hukkanen MV, Polak JM, Rutherford OM. Decreased nitric oxide levels and bone turnover in amenorrheic athletes with spinal osteopenia. The Journal of Clinical Endocrinology \& 
UNDERGRADUATE RESEARCH IN NATURAL AND CLINICAL SCIENCE AND TECHNOLOGY (URNCST) JOURNAL Read more URNCST Journal articles and submit your own today at: https://www.urncst.com

Metabolism. 1998 Sep 1;83(9):3056-61.

https://doi.org/10.1210/jcem.83.9.5106

[44] Jungersten L, Edlund A, Petersson AS, Wennmalm A. Plasma nitrate as an index of nitric oxide formation in man: analyses of kinetics and confounding factors. Clinical Physiology. 1996 Jul;16(4):369-79. https://doi.org/10.1111/j.1475-097x.1996.tb00726.x

[45] Rodriguez-Plaza LG, Alfieri AB, Cubeddu LX. Urinary excretion of nitric oxide metabolites in runners, sedentary individuals and patients with coronary artery disease: effects of $42 \mathrm{~km}$ marathon, $15 \mathrm{~km}$ race and a cardiac rehabilitation program. Journal of Cardiovascular Risk. 1997 Jan 1;4(5-6):367-72. https://doi.org/10.1177/174182679700400509

[46] Hoch AZ, Jurva J, Staton M, Vetter C, Young C, Gutterman D. Is endothelial dysfunction that is associated with athletic amenorrhea reversible? Medicine \& Science in Sports \& Exercise. 2003 May 1;35(5):S12. https://doi.org/10.1097/00005768200305001-00058

[47] Rodríguez-Pascual F, Busnadiego O, Lagares D, Lamas $\mathrm{S}$. Role of endothelin in the cardiovascular system. Pharmacological Research. 2011 Jun 1;63(6):463-72. https://doi.org/10.1016/j.phrs.2011.01.014

[48] Juan S-H, Chen J-J, Chen C-H, Lin H, Cheng C-F, Liu $\mathrm{J}-\mathrm{C}$, et al. $17 \beta$-Estradiol inhibits cyclic strain-induced endothelin-1 gene expression within vascular endothelial cells. American Journal of Physiology: Heart and Circulatory Physiology. 2004 Sep 1;287(3):H1254-61. https://doi.org/10.1152/ajpheart .00723 .2003

[49] Wingrove CS, Stevenson JC. 17 $\beta$-Oestradiol inhibits stimulated endothelin release in human vascular endothelial cells. European Journal of Endocrinology. 1997 Aug;137(2):205-8. https://doi.org/10.1530/eje.0.1370205

[50] Mathew V, Hasdai D, Lerman A. The role of endothelin in coronary atherosclerosis. Mayo Clinic Proceedings. 1996 Aug 1;71(8):769-777. doi: 10.1016/S0025-6196(11)64842-8

[51] Panza JA, Casino PR, Kilcoyne CM, Quyyumi AA. Role of endothelium-derived nitric oxide in the abnormal endothelium-dependent vascular relaxation of patients with essential hypertension. Circulation. 1993 May;87(5):1468-74. https://doi.org/10.1161/01.cir.87.5.1468

[52] Gužič-Salobir B, Keber I, Seljeflot I, Arnesen H, Vrabič L. Combined hormone replacement therapy improves endothelial function in healthy post-menopausal women.
Journal of Internal Medicine. 2001 Dec;250(6):508-15. https://doi.org/10.1046/j.1365-2796.2001.00910.x

[53] Tyree CM, Zou A, Allegretto EA. 17 $\beta$-Estradiol inhibits cytokine induction of the human E-selectin promoter. The Journal of Steroid Biochemistry and Molecular Biology. 2002 Mar 1;80(3):291-7. https://doi.org/10.1016/S0960-0760(02)00022-5

[54] CDC. All About Adult BMI [Internet]. Centers for Disease Control and Prevention. 2020 [cited 2020 Dec 30]. Available from: https://www.cdc.gov/ healthyweight/assessing/bmi/adult bmi/index.html

[55] Moncada S, Higgs EA. The discovery of nitric oxide and its role in vascular biology. British Journal of Pharmacology. 2006 Jan;147(S1):S193-201. https://doi.org/10.1038/sj.bjp.0706458

[56] Endemann DH, Schiffrin EL. Endothelial Dysfunction. Journal of the American Society of Nephrology. 2004 Aug 1;15(8):1983-92. https://doi.org/10.1097/01.ASN. 0000132474.50966.DA

[57] Yang X-P, Reckelhoff JF. Estrogen, hormonal replacement therapy and cardiovascular disease. Current Opinion in Nephrology and Hypertension. 2011 Mar;20(2):133-8. https://doi.org/10.1097/MNH.0b013e3283431921

[58] Stevens VL, Hoover E, Wang Y, Zanetti KA. PreAnalytical Factors that Affect Metabolite Stability in Human Urine, Plasma, and Serum: A Review. Metabolites. 2019 Jul 25;9(8):1-20. https://doi.org/10.3390/metabo9080156

[59] Martin KA, Barbieri, RL. Treatment of menopausal symptoms with hormone therapy. UpToDate [Internet]. 2020 June 24 [cited 2020 Oct 30]. Available from: https://www.uptodate.com/contents/treatment-ofmenopausal-symptoms-with-hormone-therapy\#H21

[60] Valdes A, Bajaj T. Estrogen Therapy. Treasure Island (FL): StatPearls Publishing; 2020 May 30

[61] Cumming, D. C. (1996). Exercise-associated amenorrhea, low bone density, and estrogen replacement therapy. Archives of Internal Medicine. 1996 Oct 28;156(19):2193-2195. https://doi.org/10.1001/archinte.1996.00440180051005

[62] Issued on behalf of the Board of the International Menopause Society by, Pines, A., turdee, D. W., Birkhäuser, M. H., Schneider, H. P., Gambacciani, M., \& Panay, N. (2007). IMS updated recommendations on post-menopausal hormone therapy. Climacteric. 2007 Jun;10(3):181-94. https://doi.org/10.1080/13697130701361 
UNDERGRADUATE RESEARCH IN NATURAL AND CLINICAL SCIENCE AND TECHNOLOGY (URNCST) JOURNAL Read more URNCST Journal articles and submit your own today at: https://www.urncst.com

Article Information

Managing Editor: Jeremy Y. Ng

Peer Reviewers: Jennifer Williams, O’Llenecia Walker

Article Dates: Received Jan 01 21; Accepted Feb 16 21; Published Apr 1421

Citation

Please cite this article as follows:

Sadat Afjeh N, Lamba P, Eski A. Potential impact of exercise-associated amenorrhea and subsequent estrogen therapy on cardiovascular disease risk factors in pre-menopausal athletes: A research protocol. URNCST Journal. 2021 Apr 14: 5(4). https://urncst.com/index.php/urncst/article/view/237

DOI Link: https://doi.org/10.26685/urncst.237

Copyright

(C) Niki Sadat Afjeh, Priyanka Lamba, Alefiya Eski. (2021). Published first in the Undergraduate Research in Natural and Clinical Science and Technology (URNCST) Journal. This is an open access article distributed under the terms of the Creative Commons Attribution License (https://creativecommons.org/licenses/by/4.0/), which permits unrestricted use, distribution, and reproduction in any medium, provided the original work, first published in the Undergraduate Research in Natural and Clinical Science and Technology (URNCST) Journal, is properly cited. The complete bibliographic information, a link to the original publication on http://www.urncst.com, as well as this copyright and license information must be included.

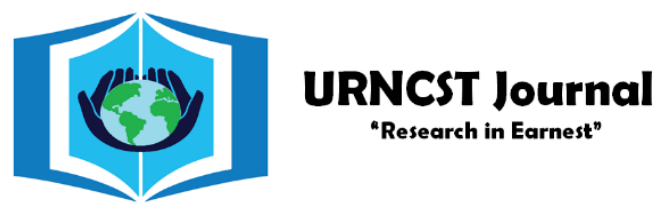
Funded by the
Government of Canada

Canadằ

Do you research in earnest? Submit your next undergraduate research article to the URNCST Journal!

| Open Access | Peer-Reviewed | Rapid Turnaround Time | International | | Broad and Multidisciplinary | Indexed | Innovative | Social Media Promoted |

Pre-submission inquiries? Send us an email at info@ urncst.com | Facebook, Twitter and LinkedIn: @URNCST

Submit YOUR manuscript today at https://www.urncst.com! 